\title{
Ultrasound and Risk Survey Evidence for Cystic Echinococcosis in La Rioja Province, Argentina
}

\author{
Héctor Danoy Villa Micó, ${ }^{1 *}$ R. Salomé Ranalli, ${ }^{2}$ Lara Estefanía Hoffmann, ${ }^{2}$ and Hugo Eduardo Bazán ${ }^{2}$ \\ ${ }^{1}$ Instituto Multidisciplinario de Salud, Tecnología y Desarrollo, CONICET-UNSE, Provincia de Santiago del Estero, Argentina; ${ }^{2}$ Departamento de \\ Epidemiología. Ministerio de Salud, Provincia de La Rioja, Argentina
}

\begin{abstract}
Hydatidosis is a zoonosis of worldwide distribution with endemic areas in Argentina. The present epidemiological study was conducted to explore the presence of cystic echinococcosis in the rural community of Los Bordos (population 99), in the northern province of La Rioja, Argentina, during March 2018. The study included the search for cysts by abdominal ultrasound and a survey on family risk. Sixty-seven people agreed to undergo ultrasound examination, and five adults showed images compatible with hydatic cysts (7.5\% prevalence). A family survey was applied to 29 households (78\%), stratifying 24 families (83\%) as high risk (95\% confidence interval $=64.2-94.1)$ and 5 (17\%) as low risk (95\% confidence interval $=5.8-55.7$ ) of transmission of the disease, respectively. The values were statistically different by the McNemar test. The goal of the present study, the first study of its kind in La Rioja, was to assess the family risk of echinococcosis among subjects with ultrasound images compatible with cystic echinococcosis.
\end{abstract}

Hydatidosis or cystic echinococcosis (CE) is a zoonosis caused by the larval stage of the cestode Echinococcus granulosus, with worldwide distribution and endemic presence in various regions of Argentina, ${ }^{1,2}$ where practically all provinces report the disease. The province of La Rioja, in northwestern Argentina, is divided into six health geographical areas (Supplemental Material 1). Most (67\%) cases in the last eight years (2010-2018) affected females, with origin in the health area 5, and a $2: 1$ ratio of adults to children. ${ }^{3}$ A provincial study was carried out during the years 2013-2014, which determined the presence of Echinococcus spp. antigen in dog feces, with distribution in all six sanitary areas. ${ }^{4}$ In September 2017, a confirmed case of a 7-year-old child with a diagnosis of cerebral CE was reported from the town of Los Bordos, belonging to the health area 5 .

The rural town of Los Bordos (population 99, distributed in 37 homes) is located $12 \mathrm{~km}$ from the city of Chamical, the departmental capital city, and $140 \mathrm{~km}$ from the province's capital city. The main economic activity of the area is the raising of goats. ${ }^{5}$

The search for hydatid cysts in asymptomatic humans is part of the epidemiological surveillance of this pathology. ${ }^{6}$ Ultrasound examinations can be performed at all ages, however, they are usually performed in children and risk groups. ${ }^{2}$ The use of abdominal ultrasound was standardized in the 1990s in Rio Negro, Argentina, recording 100\% sensitivity and $96-97 \%$ specificity in detecting the disease with liver localization. . $^{1,7-10}$

Taking into account the provincial notification of the adultsto-children ratio, a methodological approach was developed for the stratification of family risk, where a suspicious case is defined as any person positive for ultrasound screening, using the Gharbi ultrasound classification that is associated with epidemiological aspects of the disease. ${ }^{11}$

The family risk stratification process was based on the methodological proposal of risk epidemiological stratification, which emerged in the 1990s. ${ }^{12}$ The procedure, which is part of the integrated diagnosis-intervention-evaluation process,

*Address correspondence to Héctor Danoy Villa Micó, IMSaTeD, Instituto Multidisciplinario de Salud, Tecnología y Desarrollo, CONICET-UNSE, Villa El Zanjón, Santiago del Estero, Ruta Nacional No 9, Km 1125, 4206, Argentina. E-mail: hectordanoy@ gmail.com was initially used to spatially size malaria distribution in the Americas, ${ }^{13}$ and later extended to communicable and chronic noncommunicable diseases. ${ }^{14}$ This procedure allows identifying families with either low or high risk of disease transmission, based on existing knowledge about the natural history of the disease and factors associated with statistical significance, compiled from guides from the Pan American Health Organization (PAHO), the national and provincial health departments, and literature searches. ${ }^{1,2,7,8,15-17}$

To carry out the stratification procedure, a Family Epidemiological Survey (FES) on CE was implemented, which is characterized by closed-end questions containing variables oriented to the presence of components of the cycle of transmission of the disease. Families were thus stratified in high or low risk of transmission (Supplemental Material 2). Families considered to be at high risk of transmission fulfilled the following criteria: raising livestock, fishing at home or in open field, having dogs, and not deworming. The present study considered that the mere fact of having a family history of CE was a high risk of transmission. ${ }^{2,18-20}$ Conversely, families considered to have a low risk of transmission complied with having some of the characteristics of the interruption of the parasitic cycle. These characteristics included having no dogs, deworming dogs with praziquantel, or not raising livestock. In addition, a Hydatidosis Prevention Survey (HPS) was also developed, which was characterized by closed-end questions. This survey was applied to each individual that appeared to the screening and contained variables oriented toward the identification of factors associated with the cycle of transmission of the disease (Supplemental Material 3).

The present study aimed to assess the family risk of echinococcosis among subjects with ultrasound images compatible with CE in the rural community of Los Bordos, La Rioja, Argentina.

A cross-sectional study was conducted in March 2018. Abdominal ultrasound screening was performed with a portable ultrasound model Mindray Z6, 3.5 MHz convex transducer (Mindray Med Intl Ltd, Shenzhen, People's Republic of China) on the entire population. All Los Bordos residents more than 5 years old, who were clinically asymptomatic and consented to have an abdominal ultrasound taken, were included in the study. Individuals with either skin lesions in the abdominal region, diagnosed with an abdominal tumor, or acute abdomen at the time of the study were excluded. 
The epidemiological stratification of risk was carried out by application of the FES at homes in the community, taking into account that households were permanently inhabited, without limitation in the number of inhabitants. Please note that for the present study, a family is defined as consisting of two or more people related by birth, marriage, or adoption residing in the same housing unit, whereas a household may consist of any person living alone or with multiple unrelated individuals. Interviews were conducted with any adult in the family, not necessarily the head of the family. The epidemiological software Epi Info $^{\text {TM }} 7$ PC was used for the preparation, collection, processing, and analysis of the FES and HPS data, as well as for the stratification of risk from coding in a read-only field in the FES. Ethical criteria followed government guidelines and included acceptance and consent of the voluntary participants, minors and adults, respectively.

Sixty-seven of the 99 people, representing $67 \%$ of the population, agreed to undergo the practice, including 14 children under the age of 15 , who represented the entire age group, and 53 (79\%) over 15 years. The distribution by gender showed a slight predominance of females (52\%). Five people with suspicious ultrasound abdominal cystic images compatible with CE were identified, which represented a $7.5 \%$ prevalence for the Los Bordos community (Table 1). Two cases with type I cysts (hyaline cyst)-one with a type II cyst (cyst with detached membrane) and two other cases with type $V$ cysts (calcified cysts) - were found by the Gharbi ultrasound classification (Supplemental Material 4). The five suspected cases detected were individuals older than 15 years, three females and two males. One of the suspected cases was a direct relative of the previously reported cerebral CE case, and two others had a family history of CE.

The FES was carried out in 29 households of the 37 that make up the community (78\%). Eight individuals (singleperson households) did not agree to complete the survey. The 29 families that carried out the FES added to a total of 91 people ( $92 \%$ of the community). From the FES, 24 families (83\%) were classified with 72 people at high risk of disease transmission (95\% confidence interval $=64.2-94.1)$ and five families (17\%) with 19 people at low risk (95\% confidence interval $=5.8-55.7)$. When relating the ultrasound results with the family risk classification, we found a statistically significant association $(P<0.001)$ using the McNemar test for paired samples. As part of the family history of CE, FES

TABLE 1

Demographics of people who underwent ultrasound screening

\begin{tabular}{lcc}
\hline \multicolumn{1}{c}{ Variable } & Frequency & $\begin{array}{c}\text { Percentage } \\
(95 \% \mathrm{Cl})\end{array}$ \\
\hline $\begin{array}{l}\text { Gender } \\
\text { Female }\end{array}$ & 35 & $52(39.6-54.6)$ \\
$\quad$ Male & 32 & $48(35.4-60.3)$ \\
Age & 14 & $21(11.9-32.5)$ \\
$\quad<15$ & 19 & $28(18-40.6)$ \\
$15-35$ & 34 & $51(38.2-63.1)$ \\
$>35$ & 15 & $22(13.1-34.2)$ \\
Family history of CE & 52 & $78(65.8-86.9)$ \\
$\quad \begin{array}{l}\text { Positive } \\
\text { Negative }\end{array}$ & 5 & $7.5(2.5-16.5)$ \\
Ultrasound result & & $92.5(83.4-97.5)$ \\
$\quad \begin{array}{l}\text { Positive } \\
\text { Negative }\end{array}$ & 62 & \\
$\quad$ The table shows distributions by gender, age, and family history of the disease and results of \\
the ultrasound screening. Los Bordos (March 2018, $N=67)$.
\end{tabular}

showed four families (15 people) had at least one family member either with antecedents or surgical interventions related to the disease. Cystic lesions were found by ultrasound in three people (20\%) with family history, associating the antecedents with the presence of the disease (odds ratio $=6.2 ; 95 \%$ confidence interval $=0.9-41.6)$, which did not reach statistical significance.

For the HPS, of those who attended the ultrasound session, 20 adults agreed to undergo the ultrasound (38\% of the total number of adults). Knowledge of these people regarding the presented variables was assessed as high, since although $14(70 \%)$ reported not knowing the disease, they were able to identify the importance of several characteristics or factors associated with its transmission. Among the identified characteristics, it is highlighted that $14(70 \%)$ individuals recognized that it is a disease transmitted by dogs and 19 (95\%) recognized that fishing and feeding dogs raw viscera is a risk associated with the disease (Table 2).

The present study developed a strategy for screening the entire population of Los Bordos (province of La Rioja), based on the demographic characteristics of the community and methodological risk stratification tools, through the application of a family survey. This methodology arose from the notification of symptomatic cases by the epidemiological surveillance system during the period 2010-2018, which yielded an adult-to-child illness ratio of 2:1, which increased to a 3 - 5: 1 ratio after disaggregation by specific geographic areas. This situation is supported by the study that, from a case of cerebral $\mathrm{CE}$ in a 7-year-old girl, found five adults belonging to stratified families at high risk with ultrasound suspicion of the disease.

The present study offers a useful tool for strengthening epidemiological surveillance by ultrasound screening of asymptomatic cases of CE. Early detection of the five asymptomatic suspicious cases observed by ultrasound screening makes it possible to expand on therapeutic opportunities for the community.

The application of the FES method raises questions about the population selection used for ultrasound screening, which is usually performed on children, when in fact, based on our study, risk groups should be considered. It would also be interesting for future studies to validate the FES method with greater populations.

TABLE 2

Identifying factors associated with the disease (HPS)

\begin{tabular}{|c|c|c|}
\hline Identification of factors & Frequency & Percentage $(95 \% \mathrm{Cl})$ \\
\hline Knowledge of the disease & 6 & $30(11.8-54.2)$ \\
\hline $\begin{array}{l}\text { Identifies the dog in the } \\
\text { transmission of the disease }\end{array}$ & 14 & $70(45.7-88.1)$ \\
\hline $\begin{array}{l}\text { Identifies the dog's entry into } \\
\text { the garden as a risk }\end{array}$ & 14 & $70(45.7-88.1)$ \\
\hline $\begin{array}{l}\text { Identifies as risk the entry of } \\
\text { the dog into the house }\end{array}$ & 14 & $70(45.7-88.1)$ \\
\hline $\begin{array}{l}\text { Identifies the risk of being } \\
\text { licked by the dog }\end{array}$ & 18 & $90(68.3-98.7)$ \\
\hline $\begin{array}{l}\text { Identifies as a risk feeding the } \\
\text { dog raw viscera }\end{array}$ & 19 & $95(75.1-99.8)$ \\
\hline $\begin{array}{l}\text { Identifies as a risk that the dog } \\
\text { ingests water }\end{array}$ & 17 & 85 (62.1-96.7) \\
\hline $\begin{array}{l}\text { Identifies the need of } \\
\text { deworming the dog }\end{array}$ & 20 & $100(83.1-100)$ \\
\hline
\end{tabular}

Table shows knowledge of the disease and associated factors identified by adults from Los Bordos (March 2018, $N=20$ ), who completed the HPS. 
Received November 24, 2020. Approved for publication May 31, 2021.

Published online August 23, 2021.

Note: Supplemental material appears at www.ajtmh.org.

Acknowledgments: We are grateful to the Health Team of Health Area Five for its collaboration in field activities; the teachers of School No. 349 for providing the infrastructure to perform the ultrasound, and the Neighborhood Center for their collaboration in community organization.

Financial support: The study was conducted as part of epidemiological training.

Authors' addresses: Héctor Danoy Villa Micó, IMSaTeD, Instituto Multidisciplinario de Salud, Tecnología y Desarrollo, CONICET-UNSE, Villa El Zanjón, Santiago del Estero, Ruta Nacional No 9, Km 1125, 4206, Argentina, E-mail: hectordanoy@gmail.com. R. Salomé Ranalli, Lara Estefanía Hoffmann, and Hugo Eduardo Bazán, Departamento de Epidemiología, Ministerio de Salud de La Rioja, Avenida Ortiz de Ocampo No 1700, Argentina, E-mails: salomeranalligmail.com, vetlarahoffmann@gmail.com, and bazanhugo_7@hotmail.com.

\section{REFERENCES}

1. Mabel Moral Ed., 2012. Guía para el Equipo de Salud, Enfermedades Infecciosas. Publication of Ministerio de Salud de la Nación, Buenos Aires, Argentina.

2. Larrieu E, 2017. Prevención y Control de la Hidatidosis en el Nivel Local. Publication of Pan American Health Organization.

3. Villa Micó HD, Ranalli S, Hoffmann L, Bazán HE, 2018. Situación Actual de la Hidatidosis en la comunidad de Los Bordos, Dpto. Chamical, La Rioja. XXXIII Jornadas Nacionales de Hidatidosis. Catamarca, Argentina. Rev Arg Parasitol Special Issue, Abstract, pp. 18-19.

4. Amaya JC, Moreno N, Salmaso N, Bazán E, Ricoy G, Córdoba P, Santillán Gl, 2016. Estudio de infestación de caninos con Echinococcus granulosus en la provincia de La Rioja, Argentina. Rev Argent Microbiol 48: 38-42.

5. Rejal F, 2016. Proyecto de Inclusión Socio-Económica en Areas Rurales. Publication of Ministerio de Producción de La Rioja, Argentina.

6. Larrieu E, Mercapide C, Del Carpio M, Salvitti JC, Costa MT, Romeo S, Cantoni G, Perez A, Thakur A, 2000. Evaluation of the losses produced by hydatidosis and cost/benefit analysis of different strategic interventions of control in the Province of Rio Negro, Argentina. Bol Chil Parasitol 55: 8-13.
7. Ministerio de Salud de la Provincia de Rio Negro, 2009. Normas de diagnóstico y tratamiento de la hidatidosis humana. Rio Negro, Argentina: Segunda Versión.

8. Calanni L, Correa D, 2012. Guía para el Manejo de la Hidatidosis Hepática. Publication of Ministerio de Salud de Neuquén, Argentina.

9. Larrieu E et al., 2000. Portadores asintomáticos de hidatidosis: epidemiología, diagnóstico y tratamiento. Rev Panam Sal Pub 8: 250-256.

10. Chumbe GE, Lopera BL, Barrón GE, Ninaquispe BB, Gavidia Ch, 2010. Prevalencia de hidatidosis humana mediante técnicas de imagen en Yanahuanca, Pasco. Rev Investig Vet Peru 21: 6167.

11. Gharbi H, Hassine W, Brauner M, Dupuch K, 1981. Ultrasound examination of the hydatic liver. Radiology 139: 459-463.

12. Batista Moliner R, Cañizares PF, Coutin Marie G, Rodríguez Milord D, González Cruz L, 2001. Guía para la Realización del Proceso de Estratificación Epidemiológica. Publication of Ministerio de Salud Pública, La Habana, Cuba.

13. Castillo Salgado C, 1991. Epidemiologic stratification of malaria in the region of the Americas, 1991. Bol Epidemiol 12.

14. Batista Moliner R, Coutin MG, Feal Cañizares P, González Cruz R, Rodríguez Milord D, 2001. Determinación de estratos para priorizar intervenciones y evaluación en Salud Pública. Rev Cub Hig Epidemiol 39: 32-41.

15. Gajardo Jl, Castillo MJ, 2017. Factores de riesgo para hidatidosis en estudiantes de enseñanza media de la comuna de Punitaqui, Chile. Rev Chil Infectol 34: 227-234.

16. Campos Bueno A, López Abente G, Cercadillo AM, 2000. Risk factors for Echinococcus granulosus infection: a case-control study. Am J Trop Med Hyg 62: 329-334.

17. Núñez E, Calero D, Estares L, Morales A, 2003. Prevalencia y factores de riesgo de hidatidosis en población general del distrito de Ninacaca-Pasco, Perú 2001. An Fac Med 64: 34-42.

18. Larrieu EJ, Costa MT, del Carpio M, Moguillansky S, Bianchi G, Yadon ZE, 2002. A case-control study of the risk factors for cystic echinococcosis among the children of Rio Negro province, Argentina. Ann Trop Med Parasitol 96: 43-52.

19. Larrieu E, Frider B, Andreani G, Aquino A, De La Fuente R, 1998. Hidatidosis humana: ecografía de campo para la determinación de grupos de alto riesgo en la evaluación de un programa de control. Rev Inst Trop Sao Paulo 31: 267-270.

20. Carmona $\mathrm{C}$ et al., 1998. Risk factors associated with human cystic echinococcosis in Florida, Uruguay: results of a mass screening study using ultrasound and serology. Am J Trop Med Hyg 58: 599-605. 